\title{
PROPOSING A MODEL OF GREEN SUPPLY CHAIN MANAGEMENT BASED ON NEW PRODUCT DEVELOPMENT (NPD) IN AUTO INDUSTRY
}

\author{
ALI EINIZADEH \\ Department of Business Management, Central Tehran Branch, \\ Islamic Azad University \\ AHMADREZA KASRAEI ${ }^{1}$ \\ Department of Industrial Management, Central Tehran Branch, \\ Islamic Azad University
}

\begin{abstract}
The present study is an attempt to provide a model of green supply chain management based on new product development (NPD) in the auto industry. In the present study, the method of grounded theory has been used to develop a model. The required data were collected through interviews with academic experts, auto industry managers, and a review of documented meta-data and relevant reports. The sampling continued until the saturation of categories using theoretical sampling method. The research data were analysed simultaneously with the data collection during the three stages of open, axial and selective coding. This process led to the development of the green model of supply chain management following NPD in the auto industry based on the grounded theory. The findings of this study suggest that managers must carefully consider all categories and subcategories identified in this study and have the necessary and sufficient information about each item to implement the green supply chain management successfully based on NPD in the automotive industry. Moreover, this research indicates the need to pay attention to green supply chain management based on the development of new products in the automotive industry.
\end{abstract}

Keywords: Green Supply Chain Management, New Product Development (NPD), Automotive Industry

\section{INTRODUCTION}

In industrial companies, the green supply chain tries to benefit from green logistics and enhanced performance throughout the supply chain as a strategic

Contact: Ahmadreza Kasraei, Kasrai49@yahoo.com, Department of Business Management, Central Tehran Branch, Islamic Azad University, Tehran, Iran 
instrument for sustainable competitive advantage. This attempt is made by creating utility and supply chain integration from an environmental perspective in the entire supply chain. The objectives are based on two important issues, namely green purchasing and green innovation (Wage et al., 2013). Nonetheless, environmental issues in supply chain management including product design, material selection and sources, manufacturing process, the delivery of the final product to the customer, product management after consumption, and its useful life cycle must be considered (Ansari and Sadeghi, 2014). Although the concepts of sustainable supply chain management and green supply chain management are often used interchangeably in the relevant literature, the two concepts are slightly different.

Sustainable supply chain management encompasses socio-economic dimensions and environmental sustainability. Thus, the concept of sustainable supply chain management is broader than the green supply chain management and the latter is part of sustainable supply chain management (Ahmadinejad et al., 2020). On the other hand, organisations consider social awareness and green issues to be important and necessary. Although employees did not ascertain the importance of green issues in the past, today they understand its significance and organisations become aware of the importance of introducing environmental concepts at the workplace with environmental management (Bloom et al., 2013). Research demonstrates that green management has been enforced in many countries especially in developing countries not only by laws but also by administrative arrangement such as administrative orders, technical standards, and so on (Chen et al., 2012).

Many factors are critical to the success of a new product and there is a high probability of product failure if these factors are not clearly defined. Based on this argument, it is necessary to identify and classify the success or failure factors of New Product Development (NPD) projects so that the organisation's planners can decide on the formulation and implementation of judicious programs and policies given the existing conditions and facilities (Bonner, 2010). Implementing green supply chain management as a system for the growth of auto companies will be a comprehensive approach to understanding this phenomenon. It is a phenomenon that incorporates various components including managers, entrepreneurs, the society and attention to the environment (Ahani, 2016).

In such an environment, successful companies and especially auto companies try to use green supply chain management by exploiting the current competitive advantages and discovering innovations that determine future competitive advantage as a key factor in achieving success. Nonetheless, the significance of activities based on the green supply chain management and NPD in the form of strategic entrepreneurship leads to a dramatic impact on the success of the auto industry, developing the advantage of green supply chain management and adequate resources for ongoing and future activities. On the other hand, the use of green supply chain and recognising and emphasising the conditions that facilitate the development of strategic market behaviours affect the companies' 
NPD. One of the key features of such markets is that companies benefit from the green supply chain management based on their capabilities and internal resources to improve their performance and innovations and introduce new products quickly. In practice, many managers have a limited definition of green supply chain management based on NPD process. It is possible that auto industry managers will not only fail to identify the fundamental NPD risks, but also fail to understand the opportunities for improvement to manage the green supply chain more efficiently compared to competitors (Mirza Ramazani, 2017).

Therefore, the most important problems encountered by the auto industry are rooted in supply chain issues and the development of their new products. The main reason for this case can be expressed by several main categories such as the lack of professionalism in market research and customer-oriented production, low level of technical knowledge, low level of product innovation, lack of professionalism in business management, poor management in the green supply chain and especially the stable formation of specialised work teams.

Thus, according to the above-mentioned issues, these problems can be addressed in general in the form of green supply chain and NPD process in this industry. However, the green supply chain management allows the auto industry to achieve its goals and plans by optimally applying green performance and minimising the destructive effects and harms to the environment. Moreover, important and debatable subjects in the auto industry including inflexible structure, non-transparent tasks, and crippling bureaucracy embedded in the fabric of these organizations require special measures such as the mechanisms of the green supply chain management as the axis of production strategy. These requirements enable the organisation to achieve strategic and operational goals and thus lead to the development of desirable products which have been prioritised more than ever. This being said, given the importance of recognising and analysing the green supply chain management and proper management in growing and increasing the NPD productivity, no significant efforts have been made by auto industry experts in this field. Hence, the need to design a model for the green supply chain management based on NPD is clearly important.

\section{LITERATURE REVIEW}

Green supply chain management combines supply chain management with environmental requirements in all stages of product design, selection and creating the green quality of supply chain, as well as the process of considering environmental criteria or implications throughout the supply chain (Mir Aghaei, 2020). Green supply chain management encompasses all stages of product design, the selection and supply of raw materials, production and manufacturing, distribution and transfer processes, the delivery to the customer and finally the recycling management after consumption to maximise the efficiency of energy consumption and resources and improve the performance of the entire 
supply chain (Omidvar et al., 2015). In studying the environmental effects of supply chain activities, the impacts of products on the environment are analysed using a holistic approach (including the analysis of the product life cycle from the beginning to the end of its life). In this approach, the whole gamut of ecological effects (e.g. science of habits, the way of life of organisms, and their interaction with the environment) are measured and considered for each activity in developing and designing new products at different stages of product life such as product concept, design, preparation of raw materials, construction and production, assembly, maintenance, packaging, transportation and product transfer and reuse (Lin et al., 2013).

NPD is a set of activities that begins with understanding market opportunities and ends with the creation, sale, and delivery of a product (Alrich, 2000). An organisation taps into all of its resources, facilities, and capabilities in multipurpose groups in order to create new and innovative products or develop an existing product in a process. In this sense, NPD is a basic process considered as some kind of progress and revival for the organisation (Andalib and Moghtaderi, 2018). On the other hand, the process of production and development of a new product must be tailored positively to the needs of customers and create a suitable competitive environment for the organisation by relying on technological superiority and the appropriate allocation of budget. New product development (NPD) is an important aspect of any business. New products provide growth opportunities and competitive advantage for companies (Amiri et al., 2015). The purpose of new product development is to respond to customer needs, adapt to market conditions and environmental changes, increase the profits, provide customer satisfaction and counter competitors' policies. The growing trends in the development and production of new items and their successful commercial supply to the market will shorten the product life curve and switch the focus from mass production to customized production (Andalib and Moghtaderi, 2018).

Gligor et al. (2013) showed that the management of the green supply chain is critical in achieving corporate profitability (Gligor et al., 2013). However, changes in supply chain and their consequences are unique to each company and firm. Project-oriented firms must adapt to these unique changes. In order to adapt to the environment, these companies have to accept the above considerations in adopting their internal and external strategies and structures (Tanawat et al., 2015). Despite the importance of new product development, the improvement of product development capabilities has not yet been achieved. Recent research has demonstrated that the average failure rate of product development is close to $50 \%$ and about $70 \%$ of products do not achieve the projected sales. The success of new product development depends on many factors including the market characteristics, product, strategy and process. Thus, due to the abundance of information in today's world, it is no longer necessary to collect as much information as possible; rather, capitalising on the information and turning it into applied intelligence has become important to guide organisational decisions 
in developing new products (Tanawat et al., 2015). Although NPD is one of the greatest and most important strengths, it is also among the most challenging and difficult activities of any business as success in NPD projects has become a major challenge for managers (Amiri and Yaseri, 2015). This is true while most of leading companies are well aware that the most important factor that makes them superior in global competition is the ability to launch a new product faster and more efficiently than the other competitors. Offering new products is also one of the safest ways to deal with the complexities of the world that has been demonstrated as the only reliable strategy for sustainability (Alam Tabriz et al., 2017). Nevertheless, researchers have warned in various studies that the NPD failure rate is still a matter of concern (Marco Vinisa, 2016).

In examining the impact of IT capability and supply chain integration on the performance of new product development, Ebrahimpour et al. (2015) showed that IT capability increases the performance of new product development. The moderating role of knowledge absorption capacity in the relationship between IT capability and supply chain integration and the moderating role of knowledge absorption capacity in the relationship between supply chain integration and NPD performance have been confirmed. Kianfar (2016) evaluated "the effect of entrepreneurial supply chain and NPD on the performance of companies: a case study of the beverage industry". The results showed that the three components of growth, customer participation and supplier participation in the entrepreneurial supply chain and the three characteristics of product tastes, health and diversity and innovation in new product development can affect the performance of companies.

Kevin et al. (2013) investigated the effects of supply chain relationship on new product development. The results of their article show that the company's competence in marketing information and its willingness to engage in partner relationships have direct and interactive effects on the ability to develop new products. This feature is further proven to be positively related to organisational performance and the results also show that this relationship is moderated by technology uncertainty. Fracasia et al. (2018) have examined the impact of green product development on a country. The results show that the countries that are more focused on green production have the largest GDP. Developing countries can also improve their economic performance by investing in green sectors. Meanwhile, companies tend to use green product development more for products with a competitive advantage.

In examining the future trends and challenges of green supply chain management, Ming Long et al. (2019) showed that research on the analysis of stimuli and barriers to green supply chain management is declining while using optimisation models to enhance decision-making in environmental performance and productivity has become a growing trend. To fill the gap in the theoretical literature, the grounded theory and approach and the coding method were used in the present study, while analysing, measuring and evaluating the green supply chain management based on NPD in the auto industry. The reason 
for the importance of this approach is that for reasons such as lack of available resources in the auto industry, those involved will not be able to manage the green supply chain properly. Regardless, considering the limited extent of research on green supply chain management in a systematic and multidimensional manner, the majority of the available studies describe only some parts of this approach that indicate the different conditions, strategies and management patterns of the green supply chain based on NPD and grounded theory in this study.

\section{METHODOLOGY}

The present study is considered developmental research in terms of objective, as it is an effort to understand and discover new issues in the field of management and provides a model for understanding the factors of green supply chain management by theorising based on NPD process in the auto industry. Moreover, this study falls into the category of qualitative research due to the use of qualitative data. The statistical population of the research consists of the auto industry managers. In this article, the method of judgment sampling was used due to the research structure. In this way, those who seemed to have enough field experience were selected among the marketing managers of the companies and their number reached 15. These individuals were selected over time to address any shortcomings and ambiguities after analysing and comparing each interview with the next interviews. The persuasion rule was used to determine the sample size and the sampling continued until the theoretical saturation was reached.

Theoretical saturation (theoretical adequacy) indicates the emergence of theory and a stage in which new data have not emerged in relation to the category under study, the category has found a suitable scope and the relationships between categories have been established and confirmed. Data collection instruments were interviews with the specialists. In this way, using the interview protocol, interviews were conducted with a sample of marketing managers of auto companies and the necessary information for research was extracted from the interviews. The data analysis was based on the grounded theory, coding and categorisation. In the first phase of the research, the topic is known through open interviews with the auto industry managers. Furthermore, observing the behaviour of marketing managers in depth will help the researcher to acquire a deeper knowledge of the topic. Then, following this step, the conceptual model of the research is drawn after coding and categorisation.

\section{FINDINGS}

After conducting scientific interviews with scientific and executive experts in the organization, a model of green supply chain management emerged for the auto industry NPD based on the grounded method. Of course, some aspects of this process are briefly mentioned to document the research method, validity and reliability. 


\section{AXIAL CODING}

Axial coding links categories and subcategories according to their dimensions and characteristics. Strauss and Corbin's analytical tools were used to discover how the categories are related to each other. At this stage, the performed coding has been examined in accurate and general categories based on the six conditions of the grounded theory.

\section{CAUSAL CONDITIONS}

Causal conditions include items that directly affect the management of the green supply chain of the auto industry based on the development of a new product. These factors are in some way the creator and developer of the phenomenon. In this study, the three categories of environmental approach, sustainable supply chain evaluation and supply management are the empirical factors that can create causal conditions for green supply chain management based on the NPD process in the auto industry. The categories related to causal conditions are shown in Table 1.

Table 1

Causal categories (Main categories and subcategories)

\begin{tabular}{|l|l|c|}
\hline \multicolumn{1}{|c|}{ Codes } & \multicolumn{1}{|c|}{ Subcategory } & $\begin{array}{c}\text { Main } \\
\text { Category }\end{array}$ \\
\hline $\begin{array}{l}\text { Reducing pollutants in the production process } \\
\text { Increasing green training for employees } \\
\text { Eco-friendly design } \\
\text { Development of innovative environmental ideas }\end{array}$ & Green measures & \\
\hline $\begin{array}{l}\text { Green production approach to the auto industry } \\
\text { The use of existing potential in the market and its effect on } \\
\text { green production }\end{array}$ & Creating \\
$\begin{array}{l}\text { Providing government facilities and support } \\
\text { Use of distinguishing features in product design }\end{array}$ & infrastructure & \\
\hline $\begin{array}{l}\text { Green partnership agreements } \\
\text { Active customer participation } \\
\text { Active participation of stakeholders } \\
\text { Performance standards from the supplier }\end{array}$ & & \\
\hline
\end{tabular}

\section{UNDERLYING CONDITIONS}

The underlying conditions represent a specific set of features related to the phenomenon that generally refer to the location of relevant events and happenings. In this study, flexibility, integration management, and technical capabilities are the main underlying factors of green supply chain management based on the process of developing new products in the auto industry shown in Table 2 . 
Underlying categories (Main categories and subcategories)

Table 2

\begin{tabular}{|l|l|c|}
\hline \multicolumn{1}{|c|}{ Codes } & \multicolumn{1}{|c|}{ Subcategory } & $\begin{array}{c}\text { Main } \\
\text { Category }\end{array}$ \\
\hline $\begin{array}{l}\text { Flexibility in production } \\
\text { Short product development time } \\
\text { Flexibility in volume }\end{array}$ & Flexibility & \\
\hline $\begin{array}{l}\text { Managing changes in the production process } \\
\text { Setting goals }\end{array}$ & & Integration \\
$\begin{array}{l}\text { Road map } \\
\text { Standardisation of green processes } \\
\text { System Engineering }\end{array}$ & management & \\
\hline $\begin{array}{l}\text { Using new technology } \\
\text { Absorption capacity } \\
\text { Technology infrastructure }\end{array}$ & $\begin{array}{l}\text { Technical } \\
\text { capabilities }\end{array}$ \\
\hline
\end{tabular}

\section{INTERVENTIONAL CONDITIONS}

Interventional conditions include more general terms such as time, space and culture that act as facilitators or inhibitors of strategies. In this study, the three categories of competency, environmental uncertainty and technical structure and market are considered as the categories of interventional conditions based on the management of the green supply chain and NPD in the auto industry shown in Table 3.

Table 3

Interventional categories (Main categories and subcategories)

\begin{tabular}{|l|l|l|}
\hline \multicolumn{1}{|c|}{ Codes } & \multicolumn{1}{|c|}{ Subcategory } & $\begin{array}{c}\text { Main } \\
\text { Category }\end{array}$ \\
\hline $\begin{array}{l}\text { Competency of human resources } \\
\text { Change in required skills and expertise } \\
\text { Trust-based relationships } \\
\text { Strategic vision } \\
\text { The type of technology that matches the need for new } \\
\text { product development }\end{array}$ & Competence \\
\hline $\begin{array}{l}\text { Lack of incentives through the government } \\
\text { Inability to create a competitive advantage in the green } \\
\text { supply chain process }\end{array}$ & Environmental \\
$\begin{array}{l}\text { Lack of active and voluntary approach in complying with } \\
\text { environmental standards }\end{array}$ & uncertainty & \\
\hline $\begin{array}{l}\text { Increase in the level of customer maturity } \\
\text { Changes in customer patterns }\end{array}$ & \\
$\begin{array}{l}\text { Green product supply chain management } \\
\text { Lack of transparency and clarity of the supply chain process } \\
\text { Engineering analysis of the value of green products } \\
\text { Reducing the cost and time of green design }\end{array}$ & $\begin{array}{l}\text { Technical structure } \\
\text { and market }\end{array}$ \\
\hline
\end{tabular}




\section{AXIAL PHENOMENON (CATEGORY)}

The axial phenomenon refers to the idea or phenomenon that is the basis and axis of the process to which all other major categories are related. In this study, the three categories of senior management commitment, green materials production and green goal-setting are considered as the axial categories of the green supply chain management based on the auto industry NPD which is shown in Table 4.

Axial categories (Main categories and subcategories)

\begin{tabular}{|l|l|c|}
\hline \multicolumn{1}{|c|}{ Codes } & \multicolumn{1}{|c|}{ Subcategory } & $\begin{array}{c}\text { Main } \\
\text { category }\end{array}$ \\
\hline $\begin{array}{l}\text { Senior Support Senior Management of Intellectual Capital } \\
\text { Senior management awareness } \\
\text { Development of green products infrastructure } \\
\text { Improving the skills and abilities of employees } \\
\text { Institutionalisation of green processes in production }\end{array}$ & $\begin{array}{l}\text { Management } \\
\text { commitment }\end{array}$ & \\
\hline $\begin{array}{l}\text { Strengthening the green chain system of products } \\
\text { Reusability } \\
\text { Recycling } \\
\text { Waste reduction support }\end{array}$ & Production of green \\
Reducing costs & materials & \\
\hline $\begin{array}{l}\text { Technical and economic analysis of green vehicles } \\
\text { Compliance with future legal requirements such as } \\
\text { pollution and fuel consumption } \\
\text { Adequate technical knowledge and understanding of } \\
\text { production standards }\end{array}$ & Green goal-setting \\
Promoting the safety of green products & & \\
Rating the various amenities of products & & \\
\hline
\end{tabular}

\section{STRATEGIES}

Strategies are in fact plans and actions that are the output of the axial category of the model and result in consequences. This research considers the three categories of green management, green marketing and green transportation as strategies based on the central categories of green supply chain management according to the process of new product development in the auto industry shown in Table 5.

Table 5

Category of strategies (action / reaction, main categories and subcategories)

\begin{tabular}{|c|c|c|}
\hline Codes & Subcategory & $\begin{array}{c}\text { Main } \\
\text { Category }\end{array}$ \\
\hline $\begin{array}{l}\text { Creating the right ideas } \\
\text { Determining the relationship between new green product } \\
\text { development and the target market } \\
\text { Use of international experiences } \\
\text { Achieving social commitment }\end{array}$ & Green Management & 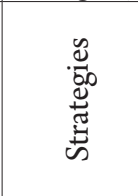 \\
\hline
\end{tabular}




\begin{tabular}{|c|c|c|}
\hline Codes & Subcategory & $\begin{array}{c}\text { Main } \\
\text { Category }\end{array}$ \\
\hline $\begin{array}{l}\text { Behavioural characteristics of different market segments } \\
\text { towards green products } \\
\text { Target market determination strategy } \\
\text { Upgrades and after-sales service evaluations }\end{array}$ & Green marketing & \multirow{2}{*}{ 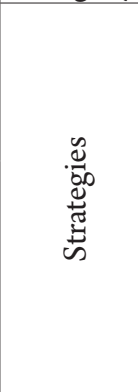 } \\
\hline $\begin{array}{l}\text { Reverse logistics practices } \\
\text { Integrated logistics activities } \\
\text { Intelligent and distinctive characteristics of the distribution } \\
\text { channel } \\
\text { Improving the quality of transportation } \\
\text { Reducing environmental impact }\end{array}$ & Green transportation & \\
\hline
\end{tabular}

\section{IMPACTS}

The last part of the Model of Green Supply Chain Management is based on the NPD process in the auto industry. Based on open coding, the concepts related to the impacts of the model are extracted. Then, these concepts are extracted and named according to the reciprocal movement between the themes and the concepts of the main categories. Accordingly, the impacts are divided into three parts related to competitive advantage, green consumption and the development of practical strategies as consequences of green supply chain management based on the process of developing new products in the auto industry. Table 6 presents the categories and concepts related to these impacts.

Table 6

Impacts category (Main categories and subcategories)

\begin{tabular}{|l|l|c|}
\hline \multicolumn{1}{|c|}{ Codes } & \multicolumn{1}{|c|}{ Subcategory } & \multicolumn{1}{|c|}{$\begin{array}{c}\text { Main } \\
\text { category }\end{array}$} \\
\hline $\begin{array}{l}\text { Developing safe and environmentally friendly products to } \\
\text { customers } \\
\text { Identifying market opportunities and threats } \\
\text { Creating dynamic structures in the green supply chain } \\
\text { The importance of the new green product in maintaining } \\
\text { the company's share and profitability }\end{array}$ & $\begin{array}{l}\text { Competitive } \\
\text { advantage }\end{array}$ & \\
\hline $\begin{array}{l}\text { Creating a good attitude in the customer to develop green } \\
\text { consumption }\end{array}$ & Green consumption \\
$\begin{array}{l}\text { Customers' desire to buy green products } \\
\text { Reuse to maximise productivity and energy consumption }\end{array}$ & \\
\hline $\begin{array}{l}\text { Upgrading and developing a sustainable green supply } \\
\text { chain }\end{array}$ & \\
$\begin{array}{l}\text { Considering environmental considerations throughout } \\
\text { the supply chain } \\
\text { Developing a roadmap for the development of advanced } \\
\text { technologies and their application in new products } \\
\text { Environmental requirements at all stages of product } \\
\text { design }\end{array}$ & $\begin{array}{l}\text { Practical strategies } \\
\text { development }\end{array}$ & \\
\hline
\end{tabular}




\section{PARADIGMATIC MODEL}

Selective coding takes into account the results of previous coding, selects the main category, and systematically links it to other categories and further develops the concept while validating it. However, selective coding begins with the integration and introduction of green supply chain management based on the process of developing new products in the auto industry identified between categories and subcategories in open and axial coding. Thus, the following graph is drawn in order to show the paradigm model better and more clearly.

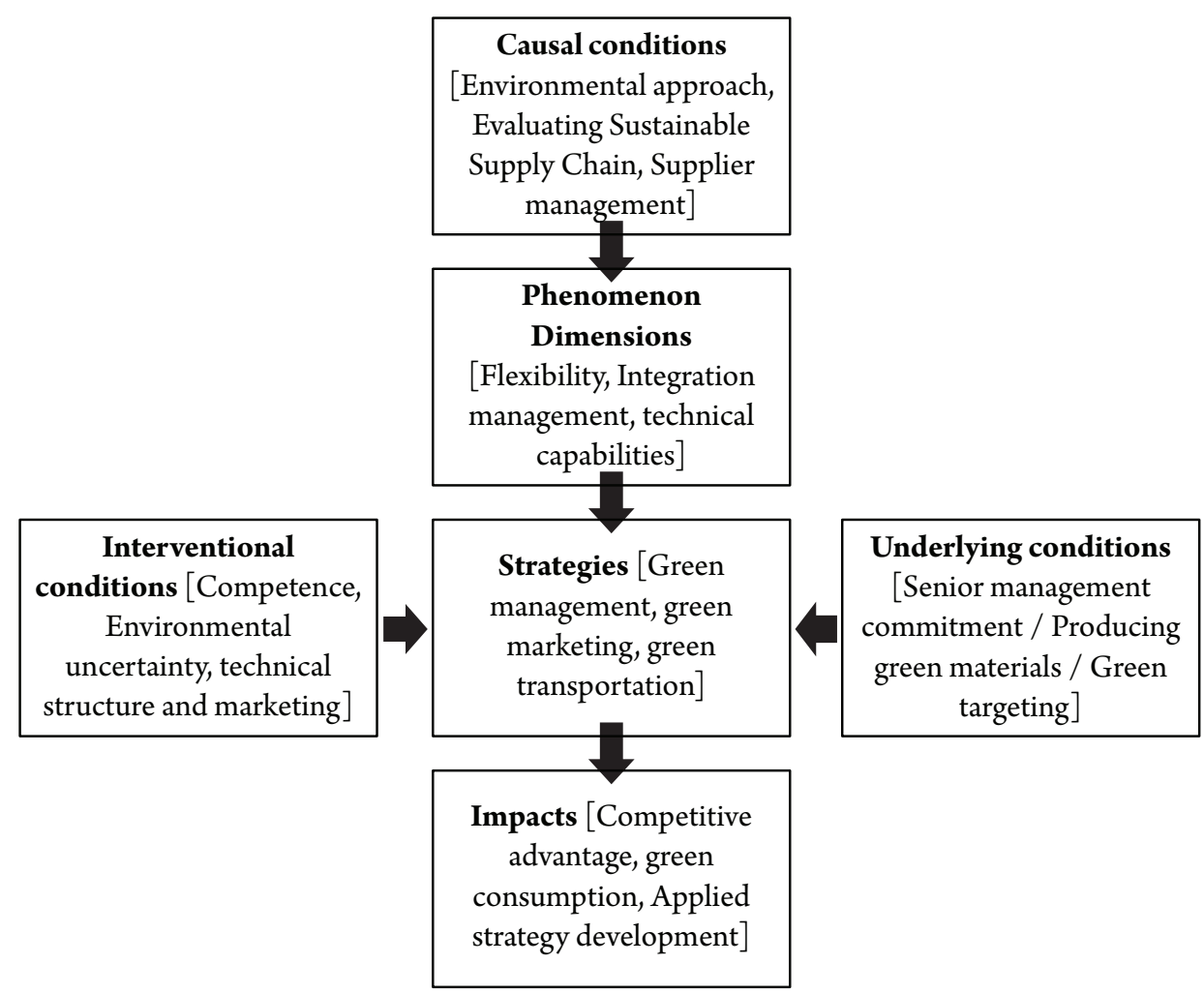

Figure 1. Research paradigm model

\section{CREATING A THEORY}

In the process of creating a theory, the main stage is the grounded theory and the researcher presents the theory based on the results of open and axial coding. Accordingly, in the paradigmatic model, causal conditions create a model of green supply chain management based on the process of developing new products 
in the auto industry. This approach may have some strengths and weaknesses that play an important role in the study and compilation of the interview in transitional situations. In the meantime, the main phenomenon and response strategies are important as they operate in an intervening context and pave the ground for the creation of a new theory. Regardless, creating the model of green supply chain management based on the process of developing new products in the auto industry has been the main concern of this research.

\section{DETERMINING THE VALIDITY OF THE THEORETICAL MODEL}

The validity of the theory was examined based on the indicators of proportionality and applicability (Strauss and Corbin, 1990) and the views of the interviewees were examined in this way. On the other hand, the proportionality index was discussed with three interviewees with regard to the research findings and the experimental world, and corrections were proposed in a number of categories. In addition, regarding the applicability index, the continuous comparison of data with the background and theoretical foundations of the research was conducted. This applicability of research was ensured by developing semi-structural questionnaires at each stage of the interviews along with corrections.

\section{CONCLUSION}

The present study was an attempt to provide a model of green supply chain management based on the NPD process in the auto industry using grounded theory. Green supply is based on the development of new products in the auto industry, which is presented in the form of the final research model. The results of research in this study show that having a higher level of methods for green supply chain management leads to higher achievements in product development. Moreover, companies activating high levels of these methods will thus achieve a high level of competitive advantage.

As shown in this study, companies must operate a higher level of green supply chain methods in order to achieve better performance. This leads to a competitive advantage in producing new products in a competitive market. The results of the present study are consistent with the conclusions of the studies conducted by Ebrahimpour et al. (2018), Frecasia et al. (2018) and Kevin et al. (2013). In their research, Kevin et al. concluded that the competence of a firm regarding marketing information and their involvement in partner relationships have direct and interactive effects on the ability to develop a new product. However, it is suggested that the auto industry that is rapidly accelerating technological change in the industry, should shift its focus from the establishment of political relations with government officials to focus on 
the creation of business networks and relationships because business partners provide reliable information to predict future changes. In this situation, trade relations affect both the acquisition of new resources and the development of new products. While political relations not only do not provide new resources, they can also negatively affect the efficacy of current methods. In this regard, bilateral trade cooperation, participation in trade union meetings, specialised exhibitions, and holding specialised conferences with other trading partners will be effective in developing new products.

The auto industry managers are required to plan and implement supply chain management processes (such as green procurement, green sourcing, green packaging, green distribution and sale, and vehicle route planning) to reduce environmental impacts. In this way, the amount of pollution is maintained within the permitted standards. This involves replacing old technologies with new ones which minimise the creation of pollutants. Therefore, the managers' commitment is crucial in making decisions about green competitive strategy to implement environment-friendly technologies. By choosing appropriate procedures and policies, managers should provide the necessary basis to create a green supply chain for their companies in order to increase the value of their company while reducing the environmental impact.

Senior managers can improve sustainable supply chain in the auto industry by applying sustainable strategies in supply chain management by linking future strategic needs with suppliers and creating collaborative teams for supply chain management consisting of the members of various companies. Managers are encouraged to allocate managerial and financial resources to provide different models on a common platform, as this approach to the domestic and foreign markets encourages and facilitates the development of new and innovative ideas about product innovations, services or processes. It will increase the value offered to the customer and lead to situational competitive advantage for car companies. In order to review the results, future researchers are recommended to identify and prioritize the factors affecting NPD using the fuzzy Delphi technique.

Given that the present research has been performed only within the auto industry, it is suggested that this research be performed in other industries, as well in order to develop the green chain management literature based on the development of new products. As with most studies based on the grounded theory, the findings of the present study are based on the views and experiences of the participants and the environmental conditions of the research; therefore, the results can be generalised in similar conditions and environments. Obtaining the consent and opinions of experts in conducting research has been another limitation of this research. Moreover, the present research was cross-sectional and, therefore, it is difficult to draw conclusions about causality. The large number of questions in the questionnaires led to the prolongation of its execution time, which might have affected the accuracy of the participants' answers. 


\section{REFERENCES}

1. Ahani, Elham (2016). Investigating and evaluating the effects of key success factors of green supply chain management on green measures and sustainable performance results. Case study: Saipa Auto Company, $5^{\text {th }}$ International Conference of Iran Auto Industry, 2016.

2. Ahmadinejad, Sahar Sadat; Karimi Zarchi, Mohammad; Fathi, Mohammad Reza (2020). Choosing a Business Strategy for Green Supply Chain Management Using Network Analysis Process Method, Human and Environment Quarterly Journal, Vol. 18, No. 1, Consecutive Iss. 52, Spring 2020, pp. 21-34.

3. Alam Tabriz, Akbar; Hamidizadeh, Mohammad Reza; Dari Nokrani, Behrooz; Mohammadi (2017). Presenting a new product development model in the country's auto industry, summer 2017, No. 26 Scientific-Research (Ministry of Science) 19ISC, pp. 33-51.

4. Amiri, Yaser, Mohammadi Ali, Mosleh Shirazi Ali Naghi, Ali Mohammadloo Moslim (2015). Designing a comprehensive process model of factors affecting new product development (NPD) in manufacturing industries. Quarterly Journal of Management and Development Process, 28 (4), pp. 139-166.

5. Andalib, Davood; Moghtaderi, Ali Akbar (2018). Investigation and Analysis of Factors Affecting Green Product Development in Yazd Province Tile Industry, New Research, Vol. 8, No. 3, Consecutive Iss. 30, Fall 2018, pp. 59-78.

6. Ansari, Iman and Sadeghi Moghadam, Mohammad Reza (2014). Identification, Determination of Relationships and Rating of Green Supply Chain Management Stimuli with Structural Interpretive Modeling Approach, Quarterly Journal of Industrial Management Studies, 12 (35), pp. 34-50.

7. Blome, C., Schoenherr, T., Rexhausen, D. (2013). Antecedents and enablers of supply chain agility and its effect on performance: a dynamic capabilities perspective. Int. J. Prod. Res. 51 (4), pp. 1295-1318.

8. Bonner, J. M. (2010). Customer interactivity and new product performance: moderating effects of product newness and product embeddedness. Industrial Marketing Management, 39(3), pp. 485-492.

9. Chen, C. C., Shih, H. S., Shyur, H, J., \& Wu, K. S. (2012). A business strategy selection of green supply chain management via an analytic network process. Computers and Mathematics with Applications, 64, pp. 2544-2557.

10. Ebrahimpour Azbari, Mostafa; Moradi, Mahmoud; Mirfallah Demochali, Rezvaneh (2018). The Impact of Information Technology Capability and Supply Chain Integration Capability on New Product Development Performance: The Role of Knowledge Absorption Capacity Adjustment, Vol. 6, Iss. 2, Summer 2018, pp. 109-136.

11. Fraccascia, L., Giannoccaro, I., \& Albino, V. (2018). Green product development: What does the country product space imply? Journal of cleaner production, No. 170, pp. 1076-1088.

12. Gligor, D. M., Holcomb, M. C., \& Stank, T. P. (2013). A Multidisciplinary Approach to Supply Chain Agility: Conceptualization and Scale Development. Journal of Business Logistics, 34(2), pp. 94-108.

13. Kevin J. Trainor, Michael T. Krush, Raj Agnihotri, (2013) Effects of relational proclivity and marketing intelligence on new product development, Marketing Intelligence \& Planning, Vol. 31, Iss. 7, pp. 788-806, https://doi.org/10.1108/MIP02-2013-0028

14. Kianfar, Kamran, Barforosh, Nasrin (2016). Evaluating the Effect of Entrepreneurial Supply Chain and New Product Development on Corporate Performance: 
a Case Study of Beverage Industry, Executive Management Research Journal: First Half of 2016, Vol. 8, No. 15; pp. 75-92.

15. Marco Leite, Vanessa Braz (2016). Agile manufacturing practices for new product development: industrial case studies, Journal of Manufacturing Technology Management, Vol. 27, Iss. 4, pp. 560-576, doi: 10.1108/JMTM-09-2015-0073

16. Ming-Lang, Tseng, Md, Shamimul, Islambc, Noorliza, Kariab, Firdaus Ahmad, Fauzib, Samina Afrin. (2019) a literature review on green supply chain management: Trends and future challenges, Resources, Conservation and Recycling. Vol. 141, February 2019, pp. 145-162.

17. Mir Aghaei, Seyed Shahriyar (2015). The Impact of Integrated Reverse Logistics on the Green Supply Chain with Emphasis on Environmental Factors, First Conference on Industrial Engineering, Economics and Management.

18. Mirza Ramezani, Abolfazl, Golestan, Hashemi, Seyed Mehdi, Naserian, Seyed Mohammad Massoud (2017). Identifying the technological risks of the new product development process and prioritizing with the network analysis process (ANP), Winter 2017, Vol. 14, No. 53, pp. 18-26.

19. Omidvar, Reza, Sardari, Ahmad, Yazdani, Nasser (2015). Ranking Barriers to Green Supply Chain Management Using Dematel Method. Case Study: Pars Khodro Co., New Marketing Research, Fifth Year, Summer 2015, No. 2 (17 consecutive).

20. Tanawat Hirunyawipada, Audhesh K. Paswan, Charles Blankson (2015). Toward the development of new product ideas: asymmetric effects of team cohesion on new product ideation, Journal of Business \& Industrial Marketing, Vol. 30, Iss. 7, pp. $855-866$.

21. Vij Nimeh, H. Abdallah, A. B. and Sweis, R. Lean supply chain management practices and performance: empirical evidence from manufacturing companies, International Journal of Supply Chain Management, Vol. 7, No. 1, 2013, pp. 1-15. 